\title{
Pemanfaatan Media Realia dengan Program Pembelajaran Individual dalam Mengenal Konsep Bilangan Bagi Anak Tunagrahita
}

\author{
Yarmis Hasan, Rila Muspita, Elsa Efrina \\ ${ }^{123}$ Universitas Negeri Padang \\ Email: yarmis.hasan@fip.unp.ac.id
}

\author{
INFORMASI ARTIKEL \\ Terkirim 05 Oktober 2018 \\ Revisi 07 Oktober 2018 \\ Diterima 31 Oktober 2018 \\ Kata kunci: \\ media realia,ppi,konsep bilangan,anak \\ tunagrahita
}

\begin{abstract}
ABSTRAK
Tulisan ini membahas tentang pemanfaatan media realia dengan penggunaan program pembelajaran individual dalam mengenal konsep bilangan bagi anak tunagrahita.Data didapatkan dengan pengamatan, wawancara, telah, dan komunikasi. Hasil menunjukkan media realia dapat mengenal konsep bilangan dengan guru sebagai teacher center. Guru mengaplikasikan media realia dengan pendekatan bermain seperti menghitung jumlah permen,pensil,atau apel. Sehingga anak lebih mudah mengenal konsep bilangan. Dari satu sampai lima dari pertanyaan anak dapat membilang atau menyebutkan, menunjukkan, membedakan, mencocokkan, menuliskan bilangan. Kemudian anak dapat menuliskan angka bilangan sesuai banyak benda.
\end{abstract}

\section{Pendahuluan}

Media merupakan penghantar pesan kepada penerima pesan agar mudah dipahami. Media realia yang dimaksud dalam tulisan ini adalah media nyata yang dapat diberikan sesuai yang ada di lingkungannya atau membantu untuk belajar. (Fauziah,2017)

Layanan belajar secara individual bertujuan untuk meningkatkan kualitas pembelajaran. Anak tunagrahita yang mengalami gangguan intelektual sulit memahami konsep bilangan. Bilangan merupakan suatu ide yang bersifat abstrak bilangan memberi keterangan mengenai jumlah suatu bilangan yang di nyatakan dalam suatu lambang bilangan (Youla Eka Ningsih Paimin 1998:7). Anak tunagrahita mengalami hambatan-hambatan, punya kesulitan dalam tugas akademik, komunikasi, dan sosial. Oleh sebab itu mereka memerlukan layanan secara khusus yaitu secara individual. Dalam pembelajaran guru perlu memiliki strategi dan media pembelajaran yang bervariasi sesuai dengan kemampuan peserta didik. Karena media merupakan segala sesuatu yang dapat digunakan merangsang pikiran, perasaan dan minat serta perhatian siswa sedemikian rupa. Sehingga hasil belajar dapat dicapai seoptimal mungkin.

Sekolah luar biasa Perwari Padang dijadikan objek penelitian bagi anak tunagrahita dalam pemanfaatan media realia dalam pelaksanaan pembelajaran individual (PPI) untuk mengenal konsep bilangan. merupakan rancangan strategi pengajaran yang peka terhadap perubahan anak sesuai dengan Amin (1995) proses belajar anak tunagrahita berlangsung lamban sehingga memerlukan waktu yang lama dalam belajar. Strategi pembelajaran adalah ilmu dan seni menggunakan sumber daya untuk menentukan kebijakan atau rencana yang cermat tentang berbagai kegiatan atau dengan kata lain sebagai proses atau cara dan perbuatan untuk menjadikan seseorang itu belajar. Menurut Hamzah B.Uno (2011:5-6) strategi pembelajaran sebagai cara yang diperoleh dan digunakan guru untuk menyampaikan pembelajaran sehingga memudahkan siswa mencapai tujuan yang diharapkan.

Media Realia merupakan objek nyata yang berhubung langsung dengan objek atau materi yang akan diberikan kepada siswa atau media tradisional yang dibagi dalam bentuk model atau manipulasi benda atau dalam bentuk aslinya. Media ini dapat digunakan sebagai alat bantu mengajar tentang konsep bilangan, karena media realia atau benda nyata yang dihadirkan kedalam kelas untuk keperluan informasi berupa benda objek aslinya (Sugiarti Vol $3: 1$ ). Konsep bilangan secara fakta yang dikenali melalui sensori kita. Menurut Suejadi (2000:14) Konsep adalah ide abstrak yang dapat digunakan untuk menjelaskan atau mengklasifikasikan sekelompok objek. Anak tunagrahita yang menjadi subjek penelitian ini adalah anak mampu didik yang memiliki keterbatasan untuk mengikuti pelajaran di sekolah reguler. Disamping punya keterbatasan tersebut mereka masih memiliki potensi yang perlu dikembangkan seperti kemampuan mengurus diri, membaca, menulis dan berhitung secara sederhana (Maria J. Wantah 2007: 15 ). Upaya guru selama ini untuk mengenalkan konsep bilangan pada siswa dengan cara membuat gambar-gambar di papan tulis kemudian guru meminta anak untuk menghitung berapa jumlah gambar tersebut, seperti gambar apel lima buah anak disuruh menghitung dan menuliskan nya. Selanjutnya terlihat anak mampu menyebutkan nya. Namun, ketika diperlihatkan bilangan lima, anak tidak bisa menunjukkan mana yang angka lima terebut. Terlihat guru tidak bervariasi dalam menggunakan media.Berdasarkan permasalahan diatas, perlu kiranya dicarikan bantuan untuk mengatasi masalah untuk mengenal konsep bilangan ini melalui pembelajaran individual dengan mengunakkan media realia, di duga pelaksanaan pembelajaran individu dapat meningkatkan pengenalan konsep bilangan tersebut.

Dari latarbelakang tersebut dapat difokuskan : Bagaimanakah pelaksanaan program pembelajaran individual (PPI) untuk mengenal konsep bilangan satu sampai lima melalui media realia bagi anak tunagrahita di SLB Perwari ?

Adapun tujuan yang dicapai pada penelitian ini adalah mendeskripsikan pelaksanaan pembelajaran individual (PPI) mengenal konsep bilangan satu sampai lima melalui media realia di SLB Perwari Padang. Pengembangan PPI menpersyaratkan berbagai jenis kegiatan, diantaranya mengikuti langkahlangkah yang sesuai dengan komponen PPI. Menurut Amin (1995 : 195): (1) Identifikasi siswa , (2) Tingkat kemampuan siswa saat ini, (3) Tujuan Jangka Panjang, (4) Tujuan Jangka Pendek. Bahan kurikulum yang jadi penekanan pertama.Program pembelajaran individual (PPI) dapat di implementasikan pada setiap anak tunagrahita yang dalam pengembangannya dilakukan asesmen terhadap kemampuan siswa 


\section{Metode}

Sasaran penelitian ini pada sekolah luar biasa $\mathrm{D}_{4} \mathrm{C}_{1}$ diberikan pelayanan dengan menggunakan media realia untuk mengenalkan bilangan satu sampai lima. Teknik pengumpulan data adalah analisa data kualitatif . Menurut Lexy Moleong (2004 : 173) ada empat kriteria yaitu kredibiliti (keterarahan), transverabiliti (ketergantungan), dependibility (kebebasan), konfirmadibility (kepastian). Adapun kriteria dalam hal ini menggunakan derajat kepercayaan atau kredibility.

Sesuai dengan kurikulum 2013 untuk anak tunagrhagita sedang dituntut beberapa pencapaian dalam pembelajaran mengenal lambang bilangan dan melakukan operasi penjumlahan . Anak sudah di tuntut pada kelas satu dengan tema diriku sub tema aku dan teman baruku. Namun dalam pengenalan lambang bilangan ini bagi anak tunagrahita sedang bukanlah perkara mudah karena anak mengalami masalah berpikir abstrak dan dibutuhkan kreatifitas guru dalam menjelaskan materi tentang pengenalan lambang bilangan dibutuhkan media semenarik mungkin agar anak tidak mudah bosan.

\section{Hasil Penelitian dan Pembahasan}

Pelaksanaan program individual atau disingkat PPI melalui pemanfaatan media realia meliputi layanan belajar mengenal konsep bilangan satu sampai lima mengikuti rancangan kegiatan pelaksanaan kegiatan dan evaluasi sebelum guru memberi layanan belajar pada siswa terlebih dahulu guru membuat rancangan yang berpatokan pada hal yang ada disekitar siswa dengan mengenal benda-benda nyata seperti permen, pensil dan buah apel sebagai benda nyata yang dapat dihitung, pensil dan buah apel. Siswa memperhatikan guru yang menghitung berapa banyak jumlah permen yang ada di tangan ibu kemudian siswa diminta untuk menghitungnya, kemudian guru memperagakan lima buah pensil dan menghitung di depan siswa " satu.. dua..tiga..empat..lima pensil" siswa diminta menghitung berapa banyak pensil yang ada di tangan ibu. Coba hitung!. Kemudian guru memperagakan dan menyebutkan angka satu sampai lima. Guru juga memperagakan lima buah apel dengan menghitung satu sampai lima, kemudian guru mengelompokkan dua buah permen dan mencocokkan angka dua disamping dua buah permen. Begitu juga tiga buah permen disampingnya ada angka tiga, kemudian empat buah permen disampingnya ada angka empat, lima buah permen disampingnya ada angka lima dan seterusnya pensil yang dikelompokan dari satu sampai lima.

Kemudian siswa diminta menghitung beberapa jumlah permen, pensil dan buah apel. Siswa diminta menghitung dan mencocokkan banyaknya permen dengan angka yang telah disediakkan untuk anak. Sebelum anak mencocokkan terlebih dahulu anak menyebutkan berapa banyak permen sesuai dengan bilangan nya. Contohnya lima buah permen dengan lima buah pensil dan lima buah apel dicocokkan dengan angka lima disebelahnya. Setelah siswa mampu membilang dengan menyebutkan, menunjukkan, membedakan, menuliskan angka tersebut sesuai bilangan nya. Contohnya disebutkan bilangan satu, anak diminta menunjukkan angka satu sampai lima, lalu kemudian anak disuruh untuk mencocokkannya, kalau permen satu dicocokkan dengan angka bilangan satu, kalau permen nya dau dengan angka dua kalau pensilnya tiga dicocokkan dengan angka bilangan tiga. Kalau permennya empat, pensilnya juga empat, apel nya empat, angkanya juga bilangan empat disisinya. Kalau permennya lima, pensilnya juga lima, apel nya lima, angkanya juga bilangan lima disisinya.

Anak menuliskan angka bilangan disesuaikan dengan banyak benda. Namun dalam menuliskan angka dua sampai lima, anak masih belum pas dalam penulisannya, contoh diminta ditulis angka tiga, anak menulis angka tiga terbalik, anak menulis angka empat, anak terlebih dahulu menulis garis vertikal baru lengkungan nya. Saat diminta menuliskan angka lima, anak menuliskan garis horizontal terlebih dahulu baru lengkunganya. Perencanaan pembelajaran individual ini dibuat oleh guru dengan melakukan asesmen terlebih dahulu untuk melihat kemampuan awal anak terhadap mengenal konsep bilangan satu sampai lima. Asesmen merupakan istilah sebagai suatu proses yang di tempuh untuk mendapat informasi yang digunakan dalam rangka membuat keputusan mengenai siswa (Hamzah B. Uno 2012:1). Dengan kemampuan awal anak itu terlihatlah anak belum mampu membilang satu sampai lima. Perencanaan ini dilakukan untuk mengenal kemampuan konsep bilangan satu sampai lima yang dilakukan guru melalui media realia atau benda nyata langsung. Perencanaan PPI ini belum sepenuhnya terealisasi sesuai dengan teori bahwa perencanaan PPI itu seharusnya melibatkan tim yang terkait dalam pengembangan nya. Tim ini tidaknya hanya dibutuhkan dalam perencanaan saja namun dalam pelaksanaannya dibutuhkan untuk menangani masalah-masalah yang terjadi pada siswa dalam pembelajaran. Contohnya dalam pengenalan konsep bilangan satu sampai lima.

Rancangan layanan belajar individual berfungsi sebagai pengontrol dalam mengidentifikasi kemampuan awal anak terhadap mengenal bilangan satu sampai lima. Oleh karena itu rancangan program harus dianggap penting dalam pengelolaan pembelajaran untuk meningkatkan kualitas pembelajaran. Terliht guru belum sepenuhnya membuat rancangan pembelajaran sesuai dengan langkah-langkah PPI seperti tidak adanya koordinasi dalam tim seperti ahli terkait.

Dari segi pelaksanaan, pelaksanaan pembelajaran individual dimulai dengan strategi persuasif dengan mengajak anak bermain bersama dengan mengenal benda yang sebenarnya dan membilang, seperti : permen, pensil dan buah apel.

Anak diminta menghitung berapa jumlah permen ini, berapa buah pensil yang ada di tangan ibu ? coba hitung! dan berapa buah apel yang ada di atas meja.Kemudian anak mencocokkan angka sesuai dengan jumlah benda yang dihitungnya. Seperti tiga buah permen diletakkan angka tiga disampingnya. Mulai dengan satu permen, satu pensil dan satu apel diletakkan angka disamping nya dari angka satu sampai lima. Layanan belajar individual ini dilaksanakan dengan media yang sebenarnya untuk mengenal konsep bilangan satu sampai lima yang dilakukan sambil bermain. Karena prinsip-prinsip bermain sambil belajar merupakan hal yang penting ( Bobby D potter 2000). Sesuai dengan prinsip pembelajaran untuk anak tunagrahita yaitu prinsip kasih sayang, prinsip keperagaan, prinsip abitasi dan rehabilitasi (Jaja Rahardja 2006). Kemudian guru meletakkan lima buah permen, lima buah pensil, dan lima buah apel. Anak diminta untuk membilang, menyebutkan, menunjukkan, membedakan dan mencocokkan angka dengan banyaknya benda, seterusnya anak diminta untuk menuliskan bilangan tersebut. Setelah anak menyebutkkan dan mencocokkan,kemudian menuliskan sesuai banyaknya benda, jika anak berhasil melakukan yang diminta guru, guru memberikan pujian atau reward dengan tepukan tangan pada siswa.

Kemudian guru meminta anak menunjukkan mana yang angka satu ? Letakkan benda sesuai dengan jumlahnya, coba angkat. Mana yang angka dua ? coba angkat. Mana yang angka tiga dan seterusnya. Siswa lalu meletakkan benda sesuai dengan angka. Seperti berapa buah apel yang ada ditangan ibu? Guru menunjukkan adanya tiga buah apel. Siswa diminta mengambil 3 buah apel. Kemudian guru mengambil empat buah pensil, "berapa buah pensil yang ada ditangan ibu, coba tunjukkan angka nya berapa?". Siswa menghitung jumlah benda di tangan ibu. " ada , lima bu". Kemudian siswa menunjukkan angka lima dan meletakkan disamping benda tersebut.

Peran guru melaksanakan pembelajaran individual ini untuk mengenal konsep bilangan satu sampai lima. Saat erat kaitannya dengan bagaimana cara guru menentukkan dan menggunakan strategi dan gaya belajar anak. Karena gaya belajar anak bermacam-macam, ada yang suka mendengar, melihat, dan melakukan. Apalagi siswa yang dihadapi oleh guru adalah anak tunagrahita yang membutuhkkan waktu belajar yang lebih lama dibandingkan dengan anak yang lain. Layanan belajar individual ini perlu di perbanyak latihan-latihan yang cukup lama agar pemahaman anak lebih bagus dan penggunaan media pembelajaran yang bervariatif sebagai konsekuensi sesuai dengan tahap belajar anak. Penggunaan media realia adalah objek yang nyata dalam penyajian yang konkrit dan semi konkrit (Azhar Arsyad 2006) hasil belajar anak diperoleh melalui pengalaman langsung, yang dilakukan secara perlahanlahan dan pelaksanaannya perlu ketelatenan dan kesabaran untuk memberi penjelasannya sesuai tahap demi tahap pada siswa. Media sebagai alat bantu dalam pengembangan aspek psikologi dasar siswa yang berkaitan dengan gangguan persepsi dan konsentrasi siswa sehingga yang di pelajari siswa menjadi lebih bermakna. Melalui bermain, membantu anak mengungkapkan pikiran, perasaan, dan percaya diri.

Tujuan bermain bagi abk (anak berkebutuhan khusus) adalah proses belajar terasa menyenangkan dan mudah sehingga anak dapat menikmatinya (Yohanne Hanko 2013:10). 
Segi evaluasi. Kegiatan evaluasi merupakan hal yang penting dilakukan dalam kegiatan pembelajaran untuk melihat tingkat kemajuan siswa dan kemampuannya dari berbagai aspek. Pelaksanaannya diadakan secara berkesinambungan sehingga dapat menyediakan informasi tentang hasil kemajuan belajar siswa. Pelaksanaannya diadakan setiap waktu selama proses PPI berlangsung sesuai dengan komponen-komponennya berupa rencana, tanggal dimulai kegiatan, untuk setiap tujuan seperti tujuan jangka pendek, tujuan jangka panjang, waktu kegiatan dan tanggal evaluasi untuk mengetahui tingkat ketercapaian tujuan hasil belajar anak.Observasi dan wawancara yang dilakukan dalam pelaksanaan PPI dalam proses pengamatan pembelajaran menggunakan media realia menggambarkan sudah terlaksananya dengan baik. Sudah dapat memperkirakan apa yang sudah di miliki dan yang belum dikuasai oleh siswa. Dari kemampuan awal anak dapat menyebutkan bilangan satu sampai lima, sudah mampu menunjukkan, membedakan, mencocokkan bilangan satu sampai lima.

Evaluasi dilaksanakan melalui tanya jawab dan unjuk kerja atau tes perbuatan dilakukan secara sederhana oleh guru. Evaluasi dikenal dengan evaluasi hasil belajar siswa, sehubungan dengan evaluasi ini Mulyono (1996:26) menjelaskan proses penilaian atau evaluasi adalah sesuatu yang berdasarkan tujuan yang telah di tetapkan, selanjutnya dengan mengambil keputusan atas objek yang di evaluasi atau dengan kata lain , Hamzah B. Uno (2013:13) menyatakan evaluasi adalah proses pemberian makna atau ketetapan kualitas hasil belajar dengan cara membandingkan angka hasil pengukuran tertentu dengan kriteria tertentu karena ada dua tujuan dan fungsi asesmen atau evaluasi yaitu : (1) untuk mengetahui kemajuan siswa, (2) untuk mengetahui tingkat efisiensi metoda yang digunakan dalam pendidikan selama jangka waktu tertentu (Hamzah B. Uno 2012:12). Evaluasi ini berhasil dilakukan dengan tes lisan, anak mampu menjawab lima pertanyaan pada waktu menyebutkan, menunjukkan, membedakan, mencocokkan, dan menuliskan angka bilangan sebanyakbenda nya.
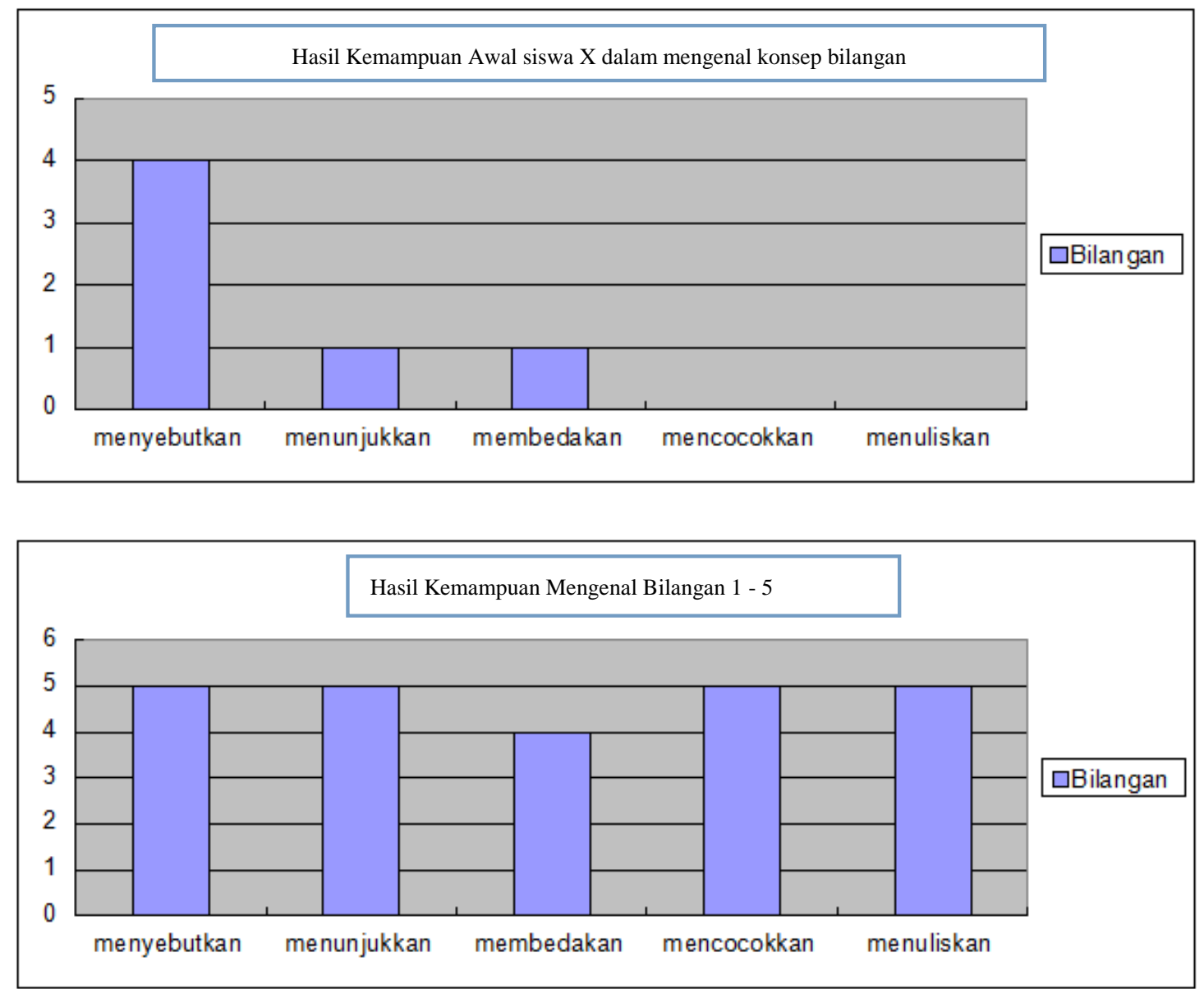

Hasil kemampuan mengenal bilangan 1 - 5, anak sudah mampu menyebutkan angka 1-5, anak sudah mampu menunjukkan 1-5, anak sudah mampu membedakan angka 1 - 4, anak sudah mampu mencocokkan 1- 5 dan anak sudah mampu menuliskan angka 1-5 walaupun masih dengan bantuan.

\section{Kesimpulan}

1. SLB Perwari Padang telah menyelenggarakan pembelajaran individual atau PPI untuk mengenal konsep bilangan 1 sampai 5 bagi anak tunagrahita namun belum sepenuhnya dikembangkan sesuai dengan teori seperti belum adanya kerjasama dengan tim ahli terkait.

2. Program individual menyangkut perencanaan, pelaksanaan dan evaluasi. Dalam kegiatan pelaksanaannya telah dilakukan asesmen yaitu menentukan kemampuan awal anak, selanjutnya dibuat rencana pembelajaran sesuai dengan kebutuhan yaitu melatih kemampuan mengenal konsep bilangan satu sampai lima dengan menggunakan media realia yang nyata yang terdapat di lingkungan anak seperti benda-benda yang disukai anak.

3. Pelaksaaan mengenal konsep bilangan dilakukan secara bertahap dengan menggunakan benda nyata melalui bermain. Anak diminta untuk dapat menyebutkan, menunjukkan, menuliskan, angka bilangan sesuai dengan banyak bendanya. Evaluasi dilakukan melalui tanya jawab secara lisan dan tes perbuatan yaitu anak dapat menunjukkan dan menuliskan angka-angka bilangan sesuai dengan banyak benda yang ada.

Daftar Rujukan

Azhar Arsyad, 2006. Media Pengajaran. Jakarta : PT Raja Grasindo Persaja. 
Deporter, Bobby and Mark Reardon \& Nourie Sarah Singer (2000). Quantum Teaching. Bandung : Kaifa.

Djadja Rahardja. 2006. Pengantar Pendidikan Luar Biasa (Introduction special education). Universitas Tsokuba : CRICED.

Endang Rohyadi. 2005. Media Pembelajaran bagi anak tunagrahita. Bandung : Depdiknas.

Hamzah B Uno. 2007. Model Pembelajaran. Jakarta : Universitas Terbuka.

Hamzah B Uno. 2012. Asesmen Pembelajaran. Jakarta : PT Bumi Aksara.

Joula Ekaningsih Paimin. 1998.Agar Anak Pintar Matematika. Manado : Puspa Swara.

Lexy. J. Molleong. 2004. Metode Penelitian Kualitatif. Bandung : PT. Rosda Karya.

Maria J, Wantah. 2007. Pengembangan kemandirian anak tunagrahita mampu latih. Jakarta : Depdiknas Dirjen Dikti.

Moh. Amin. 1995. Ortopedagogi Anak Tunagrahita. Jakarta : Depdikbud Dirjen Dikti.

Mulyono Abdurrahman. 2003. Pendidikan Bagi Anak Kesulitan Belajar. Jakarta : PT. Renika Cipta.

Soejadi. 2000. Kiat Pendidikan Matematika Di Indonesia Konstitusi Keadaan Masa Kini Menuju Harapan Masa Depan. Dirjen Dikti Depenas.

Sugiharti, S. P. (2018). Penggunaan Media Realia (Nyata) Untuk Meningkatkan Aktifitas Dan Hasil Belajar Matematika Kompetensi Mengenal Lambang Bilangan Pada Siswa Kelas I SDN 02 Kartoharjo Kota Madiun. Jurnal Edukasi Gemilang (JEG), 3(2), 7-14.(Widya, Yuliana, \& Sofiani, 2018)

Sugiharti. (2018). Penggunaan Media Realia (Nyata) Untuk Meningkatkan Aktifitas Dan Hasil Belajar Matematika Kompetensi Mengenal Lambang Bilangan Pada Siswa Kelas I Sdn 02 Kartoharjo Kota Madiun. Jurnal Edukasi Gemilang, 3(1).

Widya, W., Yuliana, T. I., \& Sofiani, Y. (2018). Pengajaran Kosakata Bahasa Inggris dengan Media Realia dan Flash Card. Jurnal PKM: Pengabdian Kepada Masyarakat, 1(1), 39-47. 